\title{
QUANTITATIVE PCR IN DIAGNOSING INFECTIOUS UROGENITAL PATHOLOGY
}

Rakhmatulina MR ${ }^{1} \otimes$, Galkina IS ${ }^{2}$

${ }^{1}$ Burnasyan Federal Medical Biophysical Center of Federal Medical Biological Agency, Moscow, Russia

${ }^{2}$ Federal Research Institute for Health Organization and Informatics of Ministry of Health of the Russian Federation, Moscow, Russia

This article describes the contemporary methods of diagnosing sexually transmitted infections, their advantages and disadvantages, indications for use. The authors describe application of quantitative polymerase chain reaction in diagnosing inflammatory diseases and dysbiotic conditions in men and women. This method, which is currently the "golden standard" in urogenital pathology diagnostics, has undeniable advantages over microbiological methods and qualitative polymerase chain reaction: the preanalytical stage requirements (preservation of quantitative ratios between microorganisms or nucleic acids of microorganisms) are not as strict, the risk of contamination from outside environment and subsequent corruption of the results is significantly smaller, the conditions for all microorganisms, including those impossible and hard to cultivate, are the same sensitivity and specificity-wise, it is possible to sample materials and evaluate microbiota (ratios of microorganisms and their groups) and also possible to collect samples non-invasively, the speed of testing is high.

Keywords: microbial biocenosis, urogenital infections, qPCR

Declarations: the authors declare a conflict of interests in connection with affiliation with DNK-Tekhnologia group of companies, developer and manufacturer of the reagents mentioned in the article.

Author contribution: Rakhmatulina MR — literature data analysis, text authoring and editing; Galkina IS — literature data analysis, text authoring.

$\triangle$ Correspondence should be addressed: Margarita R. Rakhmatulina

Novoyasenevsky Prospekt, 9, Moscow, 117588; ra.marg@yandex.ru

Received: 03.12.2019 Accepted: 18.12.2019 Published online: 25.12.2019

DOI: $10.24075 / \mathrm{brsmu} .2019 .088$

\section{ДИАГНОСТИКА ИНФЕКЦИОННОЙ УРОГЕНИТАЛЬНОЙ ПАТОЛОГИИ МЕТОДОМ КОЛИЧЕСТВЕННОЙ ПЦР}

М. Р. Рахматулина'®, И. С. Галкина²

1 Федеральный медицинский биофизический центр имени А. И. Бурназяна, Москва, Россия

2 Центральный научно-исследовательский институт организации и информатизации здравоохранения Минздрава России, Москва, Россия

В статье представлены современные методы диагностики инфекций, передаваемых половым путем, их преимущества и недостатки, показания к применению. Описаны возможности количественной полимеразной цепной реакции для диагностики воспалительных заболеваний и дисбиотических состояний у мужчин и женщин. Данный метод, являющийся в настоящее время «золотым стандартом» диагностики урогенитальной патологии, имеет неоспоримые преимущества перед микробиологическими методами и полимеразной цепной реакцией в качественном формате: менее жесткие требования к преаналитическому этапу для сохранения количественных соотношений между микроорганизмами (нуклеиновыми кислотами микроорганизмов), значительно меньший риск влияния на результат исследования контаминации образцов микроорганизмами из внешней среды, равные условия по чувствительности и специфичности для всех микроорганизмов, в том числе некультивируемых и труднокультивируемых, возможность контроля взятия материала и оценки состояния микробиоты по отношению микроорганизмов и их групп друг к другу, скорость получения результата и возможность исследования неинвазивно взятых образцов.

Ключевые слова: микробный биоценоз, урогенитальные инфекции, количественная полимеразная цепная реакция

Декларации: авторы заявляют о наличии конфликта интересов в связи с аффилиацией с группой компаний «ДНК-Технология» - разработчиком и производителем упоминаемых в статье реагентов.

Информация о вкладе авторов: М. Р. Рахматулина — анализ данных литературы, написание и редактирование текста; И. С. Галкина — анализ данных литературы, написание текста.

$\triangle$ Для корреспонденции: Маргарита Рафиковна Рахматулина

Новоясеневский проспект, д. 9. г. Москва, 117588; ra.marg@yandex.ru

Статья получена: 03.12.2019 Статья принята к печати: 18.12.2019 Опубликована онлайн: 25.12.2019

DOI: $10.24075 /$ vrgmu.2019.088

Contemporary researchers estimate that over 357 million people a year contract bacterial pathogens of sexually transmitted infections (STIs) [1, 2], and the frequency of inflammatory diseases of urogenital tract caused by aerobic and anaerobic opportunistic microorganisms reaches $80 \%$ among genital sphere pathologies [3-5].

With the aim to reduce incidence of and eliminate STIs there was developed the Global Health Sector Strategy on Sexually Transmitted Infections (2009-2016, 2016-2021). One of the missions pursued by the strategy is popularization of early diagnostics of such diseases, including symptomfree cases, since diagnosing an STI at an early stage creates optimal conditions for effective treatment and helps prevent further spread of the infectious agents [2]
Until recently, culture test was the "golden standard" in urogenital infections diagnostics. However, a significant number of etiological agents of urogenital tract infections and inflammations are hard to culture or unculturable. Besides, culture testing is labor intensive and time consuming, which significantly limits its use in routine clinical practice. Thus, there is a need for new diagnostic technology for urogenital pathology.

\section{Diagnostic methods for urogenital infections}

The current recommendation is to perform extra tests to confirm gonococcal infection diagnosed through microscopic examination only if the patient is male and the disease 
manifests itself. Microscopy has a number of deficiencies that limit its applicability significantly: the assessments of results are subjective, the sensitivity is low (30-40\%) when examining cervical, pharyngeal and rectal samples, as well as in cases of asymptomatic infections [6]. For children, pregnant women, women during menopause and in suspected cases of extragenital and complicated forms of the disease it is necessary to use culture and/or molecular biological testing methods. In N. gonorrhoeae identification, the specificity and sensitivity offered by molecular biological methods reaches $100 \%$. They are given priority in the routines of diagnosing asymptomatic forms of the disease, when a mixed infection is suspected, in screening examinations and when there are anamnestic and/or clinical signs of gonococcal infection with negative results of microscopic examination or when there are altered gram-negative or gram-stable diplococci detected $[7,8]$.

The basic methods of diagnosing urogenital trichomoniasis are native preparation microscopy, molecular biological and culture methods. Native preparation microscopy is performed immediately after sampling biological material, which limits applicability of this method. Microscopy of stained preparations is not recommended for diagnostic purposes since its sensitivity and specificity are the lowest (30-60\%) compared to other laboratory methods (Trichomonas vaginalis are often round and resemble polymorphonuclear leukocytes, and its typical morphological signs are lost during fixation and staining) [6].

Culture method's sensitivity and specificity largely depend on the composition of culture media and conditions of Trichomonas culturing. This method is more labor intensive and time consuming than molecular biological methods, the sensitivity of which is $88-97 \%$ and specificity - 98-99\%. Molecular biological testing is given priority in cases of asymptomatic trichomoniasis (most often observed in males), when there is a mixed infection suspected, in screening examinations, and also when there is a need to control the quality of microscopic examination $[5,8]$.

It is recommended to apply only the molecular biological methods, with their specificity and sensitivity approaching $100 \%[5,9]$, to validate diagnosis of chlamydial infection, diseases caused by M. genitalium, and viral STIs (anogenital herpes virus and human papillomavirus infections).

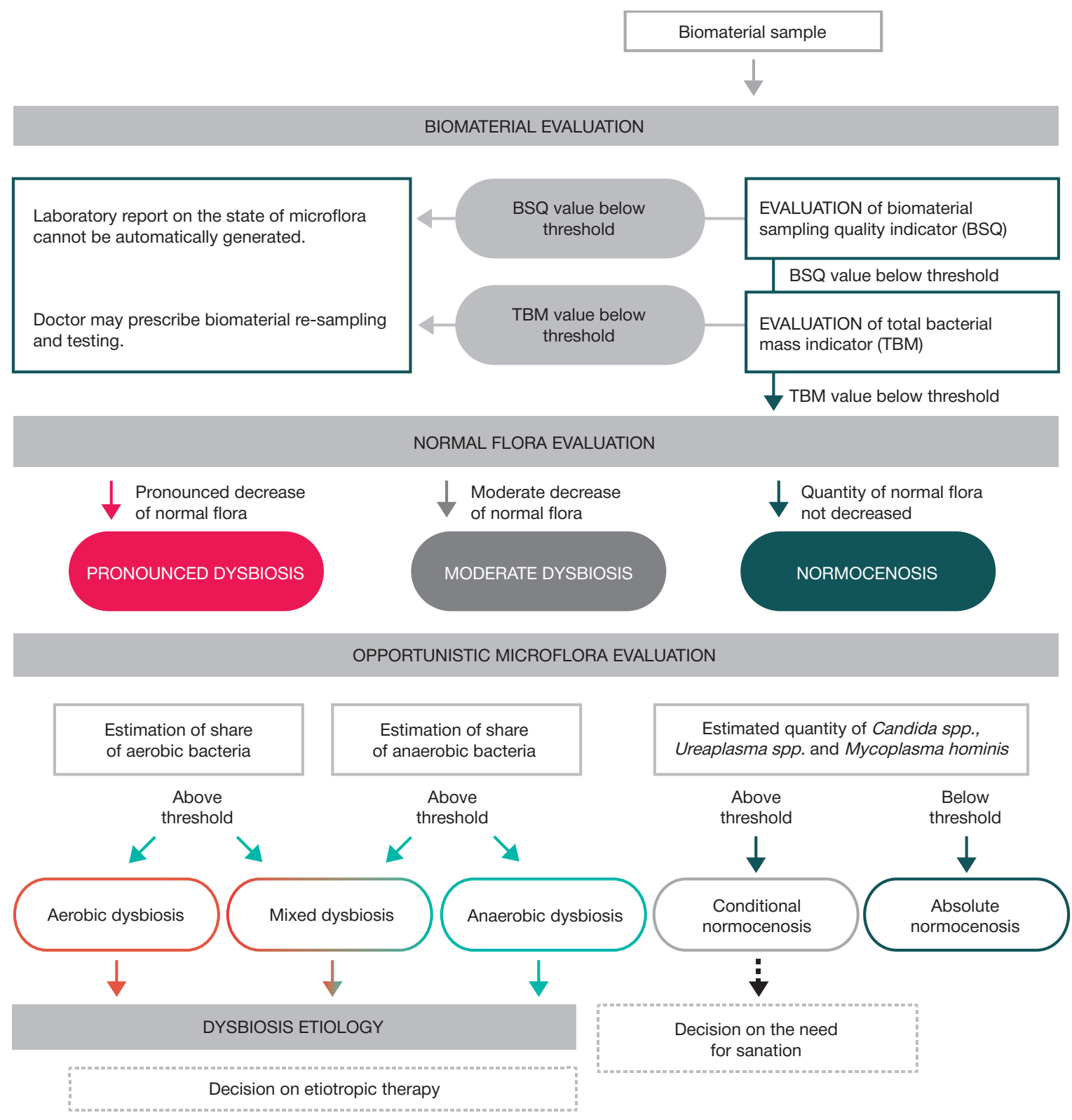

Fig. 1. The basic algorithm for interpreting urogenital tract microflora examination, female patients, real-time PCR 
Thus, molecular biological methods - polymerase chain reaction (PCR), real-time PCR (RT PCR), NASBA - were added to the official lists as methods to diagnose all sexually transmitted infections.

\section{Possibilities offered by molecular biological methods in diagnosing urogenital system pathologies}

Introduction of PCR to clinical practice had a truly revolutionary effect on identification of STIs agents. However, improperly selected genetic targets and/or various inhibitory factors can affect sensitivity of PCR. Moreover, its specificity may also be hindered by non-pathogenic representatives of the same genus/family of microorganisms present in the sample. Besides, qualitative PCR does not provide sufficient information to identify opportunistic microorganisms.

Real-time PCR is a modification of PCR that combines amplification and simultaneous detection of accumulation of its products directly during the reaction. This method allows not only to determine DNA of the microorganism but also quantify its content in the sample. Real-time PCR does not involve post-amplification analysis of reaction products and extraction of the test tube contents, which significantly lowers the risk of sample contamination and eliminates the need for a separate laboratory zone, as well as reduces testing time and augments objectivity of interpretation of its results [10].

Until recently, only the culture method allowed identification of opportunistic aerobic microorganisms, while anaerobic microorganisms, which often cause inflammatory and dysbiotic diseases of genitourinary system, remained undetected. Meanwhile, it is known that this group of bacteria often competes with lactobacilli for biotope dominance, and with dysbiotic disorders in women, it is usually obligate-anaerobic microorganisms that colonize the vaginal epithelium [11].
Today, real-time PCR enables adequate diagnostics of STIs and simultaneous detection of dysbiotic conditions (aerobic/anaerobic vaginitis, urethritis, balanoposthitis, bacterial vaginosis, etc.) resulting from an imbalance between opportunistic microorganisms and normal urinary tract microbiota. There is a number of testing systems based on this method (Florocenosis, Ampliflor, Amplisens etc.) registered in Russia; they allow qualitative and quantitative assessment of pathogenic and opportunistic aerobic microorganisms. Florocenosis and Ampliflor enable identification of lactobacilli, representatives of the Candida genus, family Enterobacteriaceae, Streptococcus spp., Staphylococcus spp., G.vaginalis, A.vaginae, opportunistic mycoplasmas, but they do not allow detecting obligate anaerobic microorganisms. Femoflor-16 and Androflor testing systems offer the widest detected range of opportunistic aerobic and anaerobic microorganisms of all the systems available. Application of these unique "paired" tests, developed for women and men, allows developing an effective algorithm for laboratory examination of couples and selection of therapy if one or both partners have infectious diseases of reproductive system or reproductive function disorders (Fig. 1, 2) [12, 13].

From the clinical point of view, one of the most important features of these testing systems is sampling quality control: the marker of sufficiency of collected epithelial cells that enter transport medium when scraping. At the early stages of examination, this indicator allows assessing adequacy of biomaterial sampling and avoiding false positive and false negative results $[14,15]$.

Absolute quantitative results of real-time PCR are given in genome equivalents (GE), the values of which are proportional to microbial contamination of urogenital biotope. However, according to some researchers, absolute quantitative indicators do not always correlate with severity of clinical picture of the disease, and values in excess of their thresholds do not always

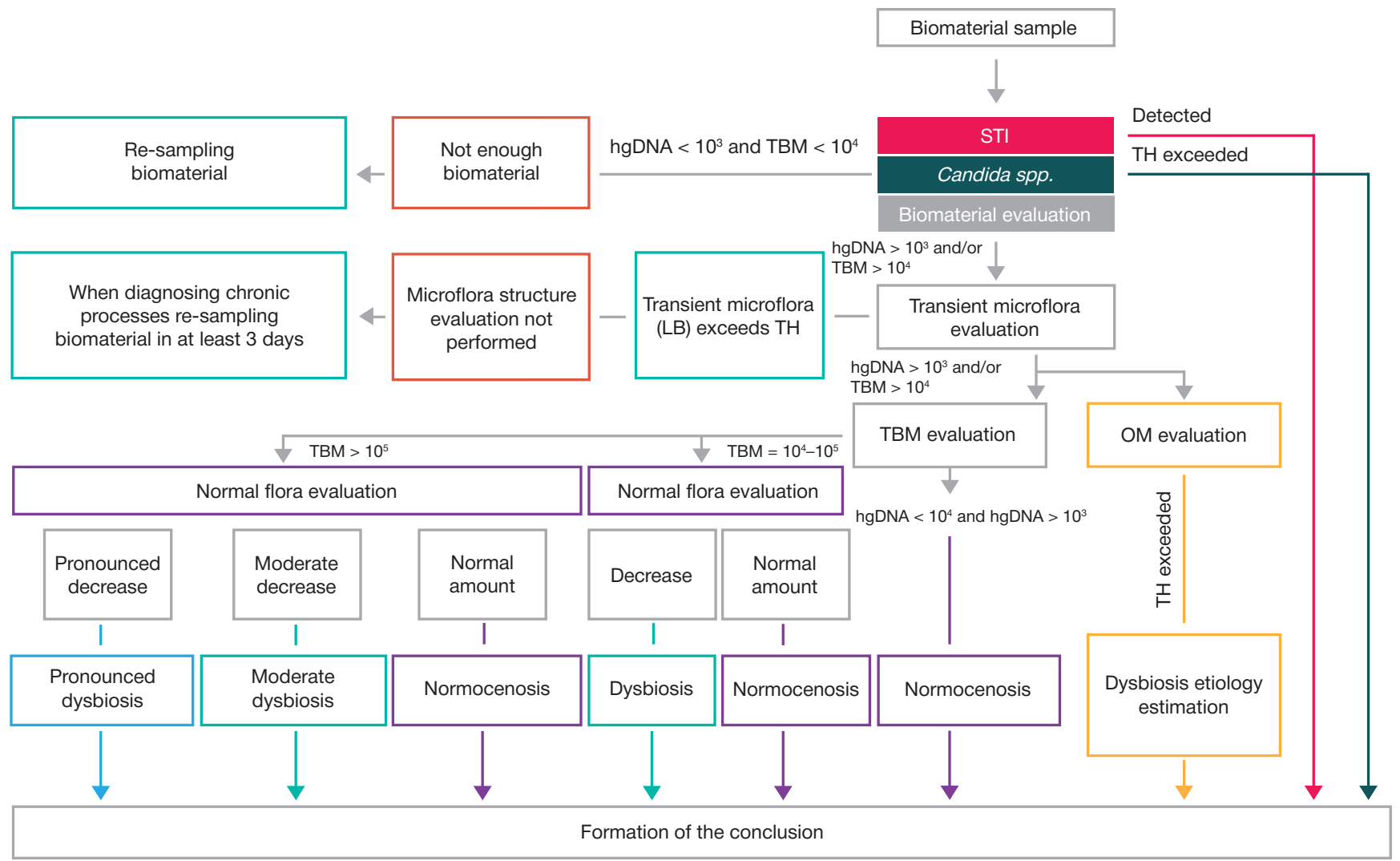

Abbreviations: TBM — total bacterial mass, hgDNA — human genomic DNA, LB — lactobacilli, OM — opportunistic microorganisms, TH — threshold value

Fig. 2. The basic algorithm for interpreting urogenital tract microflora examination, male patients, real-time PCR 
signal of clinical manifestations of an infectious-inflammatory process. Back in 1986, F. J. Roberts found a bacteriuria level below significancy in $30 \%$ of patients with clinically and laboratory confirmed bacterial infections of genitourinary tract, and in $1987 \mathrm{~J}$. A. Kellogg et al. found no correlation between clinical manifestations of urethritis and a significant level of bacteriuria. In this connection, determining the relative quantitative indicators (shares) of opportunistic microorganisms as a logarithmic difference and as a percentage of the total bacterial mass is of great practical interest. This indicator allows a specialist to assess the share of each microorganism or group of microorganisms in a specific biological sample, as well as evaluate their prevalence over other species, including normoflora, which significantly increases clinical significance of the test.

\section{CONCLUSIONS}

PCR, previously discredited as oversensitive for urogenital pathology diagnosing, justifies itself through introduction of quantitative PCR tests into routine clinical practice, which enable express testing providing a comprehensive assessment of the state of urogenital biocenosis. This approach demonstrates the ratio of key representatives of the microbial community and reduces the share of false positive and false negative results.

\section{References}

1. Ye H, Song T, Zeng X, Li L, Hou M, Xi M. Association between genital mycoplasmas infection and human papillomavirus infection, abnormal cervical cytopathology, and cervical cancer: a systematic review and meta-analysis. Arch Gynecol Obstet. 2018 Jun; 297 (6): 1377-87.

2. Global Health Sector Strategy on Sexually Transmitted Infections. 2016-2021. World Health Organization, 2016. Available from: http://www.who.int/mediacentre/factsheets/fs110/ru/

3. Khan J, Farzand R. Prevalence of Mycoplasma hominis and Ureaplasma urealyticum among women with unexplaind infertility with and without vaginitis and cervicitis. African Journal of Microbiology Research. 2011; 5 (8): 861-64.

4. Krasnoselskikh TV, Manasheva EB, Gezey MA. Komorbidnost' sifilisa i VICh-infektsii: otritsatel'nyy epidemiologicheskiy i klinicheskiy sinergizm. VICh-infektsiya i immunosupressii. 2018; 10 (3): 7-16. Russian.

5. Klinicheskie rekomendatsii po vedeniyu bol'nykh infektsiyami, peredavaemymi polovym putem, i urogenital'nymi infektsiyami. M.: DEKS-press, 2012; 112 s. Russian.

6. Dolgov W, redaktor. Klinicheskaya laboratornaya diagnostika. Uchebnik v 2 tomakh. M.: OOO «Labdiag», 2018; 624 s. Russian.

7. European Guideline on the Diagnosis and Treatment of Gonorrhoea in Adults 2012. Aavailable from: http://www.iusti.org/ regions/Europe/pdf/2012/ Gonorrhoea_2012.pdf.

8. Sexually Transmitted Diseases Treatment Guidelines, 2015. MMWR, 2015; 64 (3).

9. Lanjouw E, Ouburg S, de Vries HJ, Stary A, Radcliffe K and
Unemo M. 2015 European guideline on the management of Chlamydia trachomatis infections. Int J STD AIDS. 2016 Apr; 27 (5): 333-48.

10. Rakhmatulina MR, Shatalova AYu. Sovremennye predstavleniya o mikrobiotsenoze vaginal'nogo biotopa i ego narusheniyakh u zhenshchin reproduktivnogo vozrasta. Vestnik dermatologii venerologii. 2009; (3): 38-42. Russian.

11. Voroshilina ES, Donnikov AE, Plotko EE. Biotsenoz vlagalishcha $S$ tochki zreniya kolichestvennoy polimeraznoy tsepnoy reaktsii: chto est' norma? Akusherstvo i ginekologiya. 2011; (1): 57-65. Russian.

12. Boldyreva MN, Galkina IS. Androflor — novyy metod diagnostik zabolevaniy urogenital'nogo trakta muzhchin. Meditsinskiy alfavit. 2016; 3 (282): 40-1. Russian.

13. Borovets SYu. Diagnosticheskaya znachimost' issledovaniya mikroflory eyakulyata u bol'nykh khronicheskim bakterial'nym prostatitom metodom PCR-RT «Androflor». Urologicheskie vedomosti. 2019; 9 (S): 22-3. Russian.

14. Shipitsyna EV, Martikaynen ZM, Vorobeva NE, Ermoshkina MS, Stepanova OS, Donnikov AE, i dr. Primenenie testa Femoflor dlya otsenki mikrobiotsenoza vlagalishcha. Zhurnal akusherstva i zhenskikh bolezney. 2009; 58 (3): 44-50. Russian.

15. Fomina OV, Bolotina ES. Opyt primeneniya test-sistemy «Femoflor-skrin» dlya otsenki vaginal'noy mikrobioty. V sbornike: IKh Vserossiyskoy nauchno-prakticheskoy konferentsii s mezhdunarodnym uchastiem. Molekulyarnaya diagnostika 2017. 2017 g. Moskva: 379-80. Russian.

\section{Литература}

1. Ye H, Song T, Zeng X, Li L, Hou M, Xi M. Association between genital mycoplasmas infection and human papillomavirus infection, abnormal cervical cytopathology, and cervical cancer: a systematic review and meta-analysis. Arch Gynecol Obstet. 2018 Jun; 297 (6): 1377-87.

2. Глобальная стратегия сектора здравоохранения по инфекциям, передаваемым половым путем. 2016-2021 гг. World Health Organization, 2016. Доступно по ссылке: http://www.who.int/ mediacentre/factsheets/fs110/ru/

3. Khan J, Farzand R. Prevalence of Mycoplasma hominis and Ureaplasma urealyticum among women with unexplaind infertility with and without vaginitis and cervicitis. African Journal of Microbiology Research. 2011; 5 (8): 861-4.

4. Красносельских Т. В., Манашева Е. Б., Гезей М. А. Коморбидность сисрилиса и ВИЧ-инфеекции: отрицательный эпидемиологический и клинический синергизм. ВИЧинфекция и иммуносупрессии. 2018; 10 (3): 7-16.

5. Клинические рекомендации по ведению больных инфеекциями, передаваемыми половым путем, и урогенитальными инфекциями. М.: ДЭКС-пресс, 2012; 112 с.

6. Долгов В. В., редактор. Клиническая лабораторная диагностика. Учебник в 2-х томах. М.: ООО «Лабдиаг», 2018; $624 \mathrm{c}$.

7. European Guideline on the Diagnosis and Treatment of Gonorrhoea in Adults 2012. Доступно по ссылке: http://www. iusti.org/regions/Europe/pdf/2012/Gonorrhoea_2012.pdf.

8. Sexually Transmitted Diseases Treatment Guidelines, 2015. MMWR, 2015; 64 (3).

9. Lanjouw E, Ouburg S, de Vries HJ, Stary A, Radcliffe K, Unemo M. 2015 European guideline on the management of Chlamydia trachomatis infections. Int J STD AIDS. 2016 Apr; 27 (5): 333-48.

10. Рахматулина М. Р., Шаталова А. Ю. Современные представления о микробиоценозе вагинального биотопа и его нарушениях у женщин репродуктивного возраста. Вестник дерматологии и венерологии. 2009; (3): 38-42.

11. Ворошилина Е. С., Донников А. Е., Плотко Е. Э. Биоценоз влагалища с точки зрения количественной полимеразной цепной реакции: что есть норма? Акушерство и гинекология. 2011; (1): 57-65

12. Болдырева М. Н., Галкина И. С. Андрофлор ${ }^{\oplus}-$ новый метод 
диагностики заболеваний урогенитального тракта мужчин. Медицинский алфавит. 2016; 3 (282): 40-1.

13. Боровец С. Ю. Диагностическая значимость исследования микрофрлоры эякулята у больных хроническим бактериальным простатитом методом PCR-RT «Андросрлор». Урологические ведомости. 2019; 9 (S): 22-3.

14. Шипицына Е. В., Мартикайнен 3. М., Воробьева Н. Е., Ермошкина М. С., Степанова О. С., Донников А. Е., и др.
Применение теста Фемофлор для оценки микробиоценоза влагалища. Журнал акушерства и женских болезней. 2009; 58 (3): 44-50.

15. Фомина О. В., Болотина Е. С. Опыт применения тест-системь «Фемофлор-скрин» для оценки вагинальной микробиоты. В сборнике: IX Всероссийской научно-практической конференции с международным участием. Молекулярная диагностика 2017; 2017 г. Москва: 379-80. 